九州大学学術情報リポジトリ

Kyushu University Institutional Repository

FOUR NEW SPECIES OF THE GENUS HALICTOXENOS FROM JAPAN (STREPSIPTERA, STYLOPIDAE) (Studies on the Japanese Strepsiptera VI) PIERCE

Kifune, Teiji

Hirashima, Yoshihiro

Maeta, Yasuo

https://doi.org/10.5109/2426

出版情報: ESAKIA. 19，pp.151-160，1982-11-25. Entomological Laboratory，Faculty of Agriculture, Kyushu University

バージョン：

権利関係 : 


\title{
FOUR NEW SPECIES OF THE GENUS HALICTOXENOS PIERCE FROM JAPAN (STREPSIPTERA, STYLOPIDAE)
}

(Studies on the Japanese Strepsiptera VI)*

\author{
T EIJI K IFUNE \\ Department of Parasitology, School of Medicine, \\ Fukuoka University, Fukuoka 814-01, Japan \\ YoshiHiRo Hirashima \\ Entomological Laboratory, Faculty of Agriculture, \\ Kyushu University, Fukuoka 812, Japan \\ and \\ Y asuo Maeta \\ Laboratory of Insect Management, Faculty of Agriculture, \\ Shimane University, Matsue 690, Japan
}

\begin{abstract}
Four new species of Halictoxenos, i. e., latifemoralis, borealis, japonicus and mirabilis, are described from Japan. H. Zatifemoralis is a parasite of Lasioglossum trispine, $\mathbf{H}$. borealis is of Lasioglossum apristum, and $\mathbf{H}$. japonicus and $\mathbf{H}$. mirabilis are of Halictus aerarius. The latter two species parasitic on the same host bee are allopatric.
\end{abstract}

This paper reports the results of our recent studies on the genus Halictoxenos Pierce, 1908 of Japan. Four new species are described in this paper. Our study of Halictoxenos was begun in 1959 when we found H. latifemoralis, new species, is parasitic on Lasioglossum trispine while its biology was being studied by Hirashima and Maeta on a large colony found at Kashii, Fukuoka City. We collected not a few specimens of this stylopid at that time. Since then, we tried to collect as many specimens of Halictoxenos as possible from various parts of Japan. As a result, we were able to get only about a dozen specimens, since Halictoxenos is rare. We decided to publish our result of taxonomic

* Contribution from the Entomological Laboratory, Faculty of Agriculture, Kyushu University, Fukuoka (Ser. 3, No. 119). 
study on this collection, although this is by far from satisfaction, in order to promote the advanced study of these interesting insects.

The Japanese species of Halictoxenos are distinguishable to each other by the structures of the maxillary palpi, prothoraces and hind femora in the male and those of the mandibles and openings of brood chambers in the female.

\section{Halictoxenos latifemoralis, new species}

The occurrence of this species in Kyushu was reported at the 19th annual meeting of the Entomological Society of Japan held at Okayama City in 1959 by Hirashima and Maeta who studied the biology of its host species Lasioglos: sum trispine (Vachal).

Male (Figs. 1-6: A).

Size. Total length of body $2.9-3.0 \mathrm{~mm}$; length of head and thorax together 2.1-Z. $2 \mathrm{~mm}$; head breadth $0.7 \mathrm{~mm}$; metathoracic breadth 0.75 -0. $80 \mathrm{~mm}$; radial length of hind wing about $2 \mathrm{~mm}$; length of aedeagus $0.15 \mathrm{~mm}$.

Structure. Head transversely elongated, vertex between antenna1 basements triangularly pointed anteriorly; eyes hemispherical ; antenna 4-segmented, 1st segment cylindrical, distal end obliquely truncated, 2nd segment cup-formed, 3rd segment with flat flabellum, 4th segment flat, long, fairly longer than the flabellum of 3rd segment; mandible sword-like, distal fifth very slender; maxillary palpus 2 -segmented, distal segment almost straight, cylindrical, with blunt tip.

Prothorax trapezoidal, anterior margin slightly curved, slightly broader than posterior margin ; acrotergite more than half of breadth of posterior margin of prothorax ; mesothorax trapezoidal, posterior margin broader than the anterior, with a small circular pit near the middle of anterior margin; metathorax as broad as head, prescutum and scuti fused posteriorly; anterior margin of prescutum triangular, medianly pointed; scutellum triangular with blunt corners ; postlumbium triangular, anterior margin almost straight, posterior margin triangularly pointed with blunt tip; postscutellum conical, basal portion very broad, posterior tip rounded.

Hind wing with two detached veins between radius and media; proximal media about 3 times as long as distal media; cubitus and 1st anal vein almost reaching wing margin ; 2nd anal vein not reaching the margin ; jugal vein fairly recognizable.

Abdomen oval, usually broadest at basal third; sternites slightly sclerotized; 2nd sternite medianly weakly sclerotized; 3rd to 8th sternites quadrilateral, transversely elongated ; 9th segment pentagonal ; 10th tergite slightly trapezoidal; basal half of aedeagus conical, with a minute sharp dorsal process and short ventral projection.

Legs normal, hind femora with blunt process at the postero-interior angle. 
Female (Fig. 7: A).

Size. Total length of body about 2-2.2 mm ; cephalothoracic length 0.54$0.55 \mathrm{~mm}$, breadth 0.55 -o. $62 \mathrm{~mm}$ at the spiracles; basal breadth of abdomen 0.41-o. $43 \mathrm{~mm}$.

Stucture. Cephalothorax triangular, lateral margins almost straight in prespirazular portion, slightly constricted at the level of opening of brood chamber which is arcuate but not so strongly curved, and strongly constricted to the junction with abdomen in postspiracular portion; posterior margin of mouth gently curved.

Host : Lasioglossum trispine (Vachal) (Hymenoptera, Halictidae).

Type Material: Holotype male (Type No. 2379, Kyushu Univ.), Kashii, Fukuoka City, 23. V. 1959; paratopotypes-1 female, 31. V. 1959; 1 male, 26. V. 1959; 2 females, 11. VI. 1959; 1 male, 29. V. 1960. All of the type specimens were collected and mounted by Y. Maeta. These are deposited in the collection of Entomological Laboratory, Faculty of Agriculture, Kyushu University.

OTHER SPECIMENS EXAMined from the type locality (collected by Y. Maeta unless otherwise stated) : Mounted specimens: 1 male, 23. V. 1958 (T. Kifune) ; 1 male and 2 females, 3. VI. 1958 (T. Kifune) ; 1 male, 4. VI. 1958 (T. Kifune) ; 1 male, 28. V. 1959 ; 1 male, 31. V. 1959; 1 male, 7. VI. 1959; 1 male, 8. VI. 1960. Specimens preserved in alcohol: 2 males and 26 females, 5. III.-26. VI. 1959 \& 29. IV.-29. V. 1960.

REMARKS: This new species is distinguishable from congeneric exotic species by the characteristic shape of the hind femora in the male and the shape of the mandibles in the female.

\section{Halictoxenos borealis, new species}

Male (Figs. 1-2, 4-6: B).

Size. Total length of body $3.4 \mathrm{~mm}$; length of head and thorax together $2.1 \mathrm{~mm}$; head breadth $0.7 \mathrm{~mm}$; metathoracic breadth $0.9 \mathrm{~mm}$; radial length of hind wing $2.1 \mathrm{~mm}$; length of aedeagus $0.16 \mathrm{~mm}$.

Structure. Closely allied to the preceding species. Vertex prominently protruded anteriorly, trapezoidal ; distal segment of maxillary palpus tapering in distal fourth; prothorax rather rectangular; acrotergite half as broad as the breadth of posterior margin of prothorax; posterior margin of mesothorax almost as broad as posterior margin of head ; posterior margin of postlumbium rounded; aedeagus with minute ventral projection.

Female (Fig. 7: B).

Size. Total length of body 2.7-3.0 mm; length of cephalothorax 0.53$0.60 \mathrm{~mm}$, breadth $0.63-0.64 \mathrm{~mm}$, broadest at a little behind spiracles; basal breadth of abdomen 0.50-0. $52 \mathrm{~mm}$.

Structure. Cephalothorax triangular, prespiracular lateral margins slightly curved outwardly; postspiracular margins roundly curved, not so strongly 

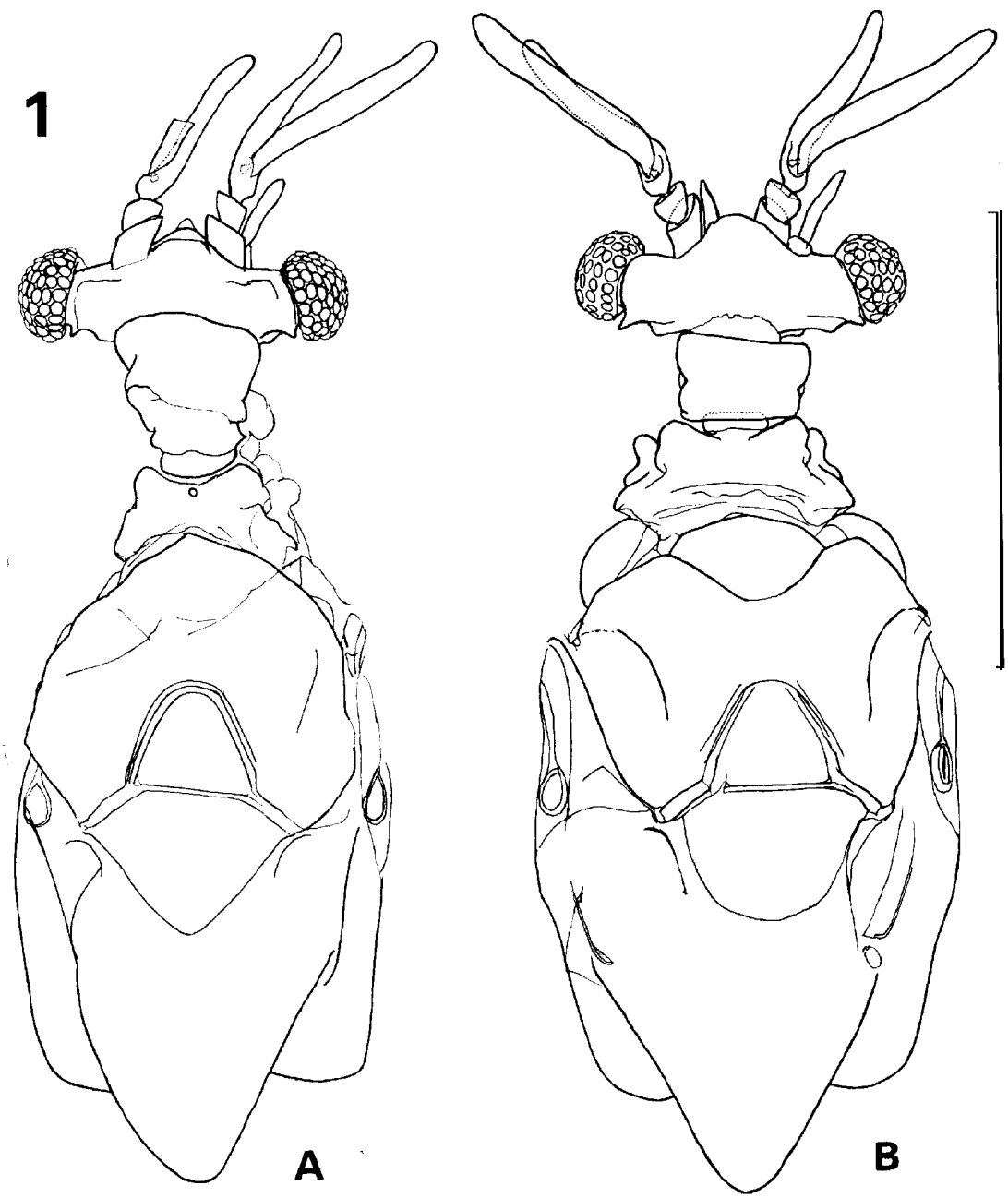

Fig, 1. Male head and thorax, dorsal view. Scale: $1 \mathrm{~mm}$. A: Halictoxe nos latifemoralis, new species. B: H. borealis, new species.

constricted towards the abdominal junction as in the preceding species; mandibles subtriangular, with triangular teeth at antero-interior angle; posterior margin of mouth elliptical.

Host : Lasioglossum apristum (Vachal) (Hymenoptera, Halictidae).

Type material: Holotype male (Type No. 2380, Kyushu Univ.) on one bee and 3 paratopotype females on another bee, Okusawa, Otaru, Hokkaido, 26. VIII. 1970 (S. F. Sakagami). All of the type specimens are mounted, and deposited in the collection of Entomological Laboratory, Faculty of Agriculture, Kyushu University.

Remarks: This is closely allied to the preceding species, but is distinguish- 


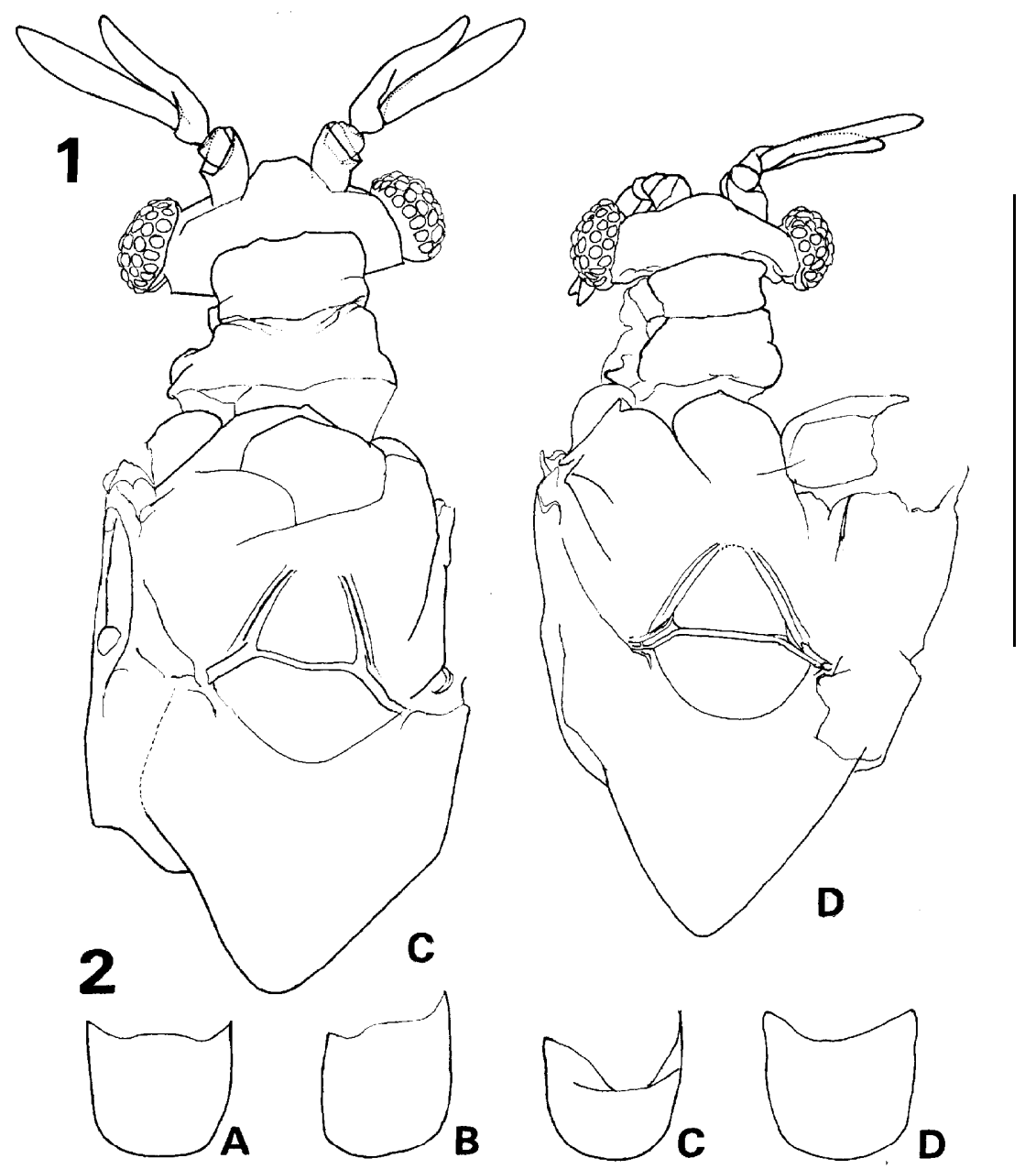

Fig. 1. C: H. japonicus, new species. D: H. mirabilis, new species. Fig. 2. Male 10th tergite (proctiger), dorsal view. Scale : $0.5 \mathrm{~mm}$. A-D: Same as in Fig. 1.

able from it by the broader mesothorax and acrotergite, round posterior margin of postlumbium, and short ventral projection of aedeagus in the male and clearly dentate mandibles and broader abdominal junction in the female.

\section{Halictoxenos japonicus, new species}

Male (Figs. 1-2, 4-6: C).

Size. Total length of body $2.6-2.8 \mathrm{~mm}$; length of head and thorax together $1.8 \mathrm{~mm}$; head breadth $0.7 \mathrm{~mm}$; metathoracic breadth $0.75 \mathrm{~mm}$; radial length of hind wing $1.7 \mathrm{~mm}$; length of aedeagus $0.15 \mathrm{~mm}$.

Structure. Head transversely elongated, vertex between antenna1 base- 


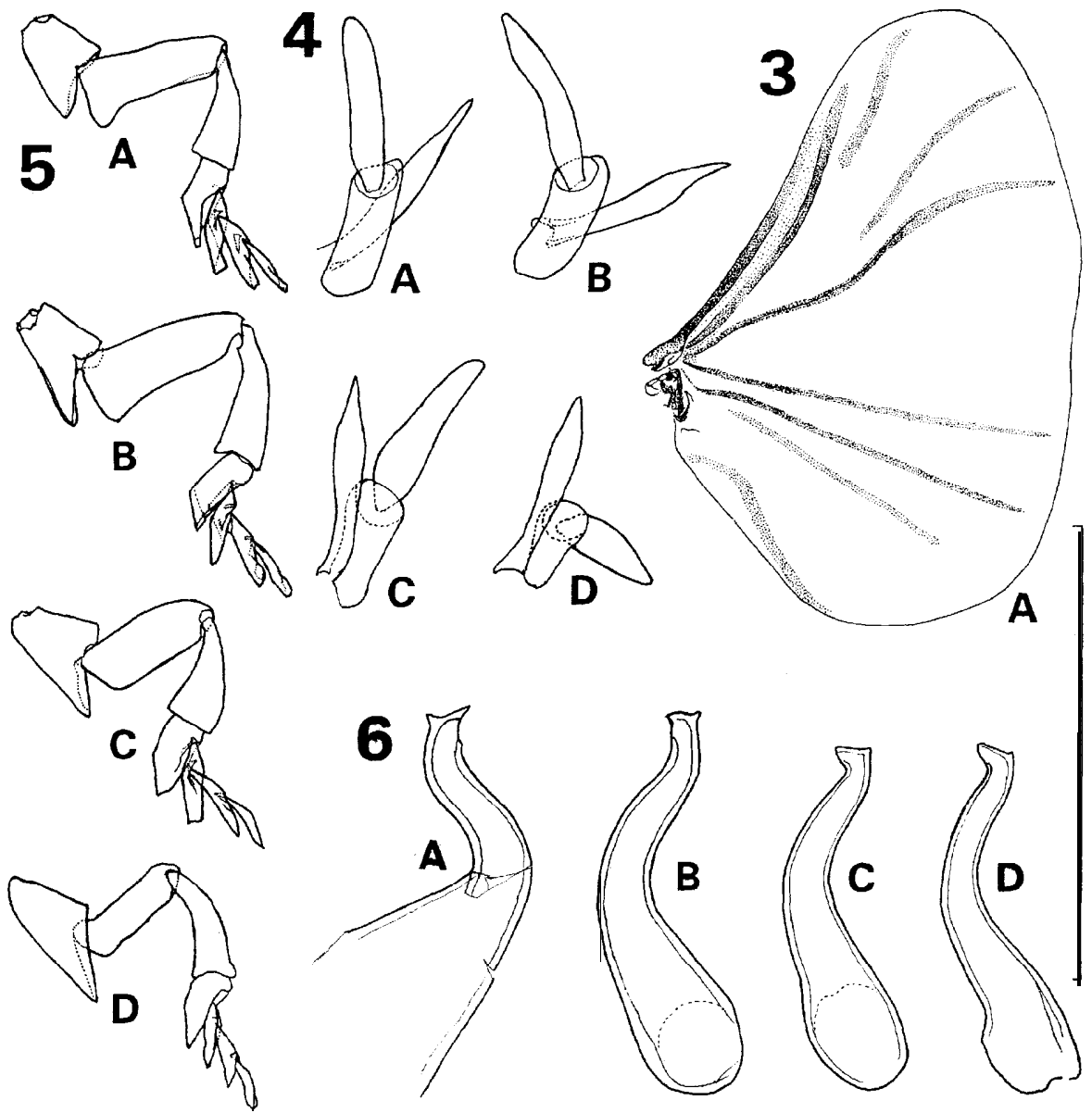

Fig. 3. Male hind wing. Scale: $2 \mathrm{~mm}$. A: Same as in Fig. 1. Fig. 4. Male mandible and maxillary palpus. Scale : $0.5 \mathrm{~mm}$. (A, B: Right, ventral view ; C, D: Left, dorsal view) A-D: Same as in Fig. 1. Fig. 5. Male right hind leg, dorsal view. Scale: 1 mm. A-D: Same as in Fig. 1. Fig. 6. Male aedeagus. Scale: $0.2 \mathrm{~mm}$. (A: Separately mounted specimen, basal portion deformed by pressure, left lateral view; B-D: Slightly obliquely sketched, right lateral view). A-D: Same as in Fig. 1.

ments trapezoidally protruded; eyes oval ; antennae 4-segmented, 1st segment broader than 2nd, 3rd segment with rather thick flabellum, 4th segment elongated, fairly longer than the flabellum of 3rd segment, distal third tapering; mandibles sword-form, broadest at apical third of its length; maxillary palpi with conical proximal segment, distal segment broadest at basal fourth of its length, with blunt tip.

Prothorax rectangular, two-thirds as broad as the interocular breadth of head ; mesothorax trapezoidal ; scutellum trapezoidal, anterior margin almost 

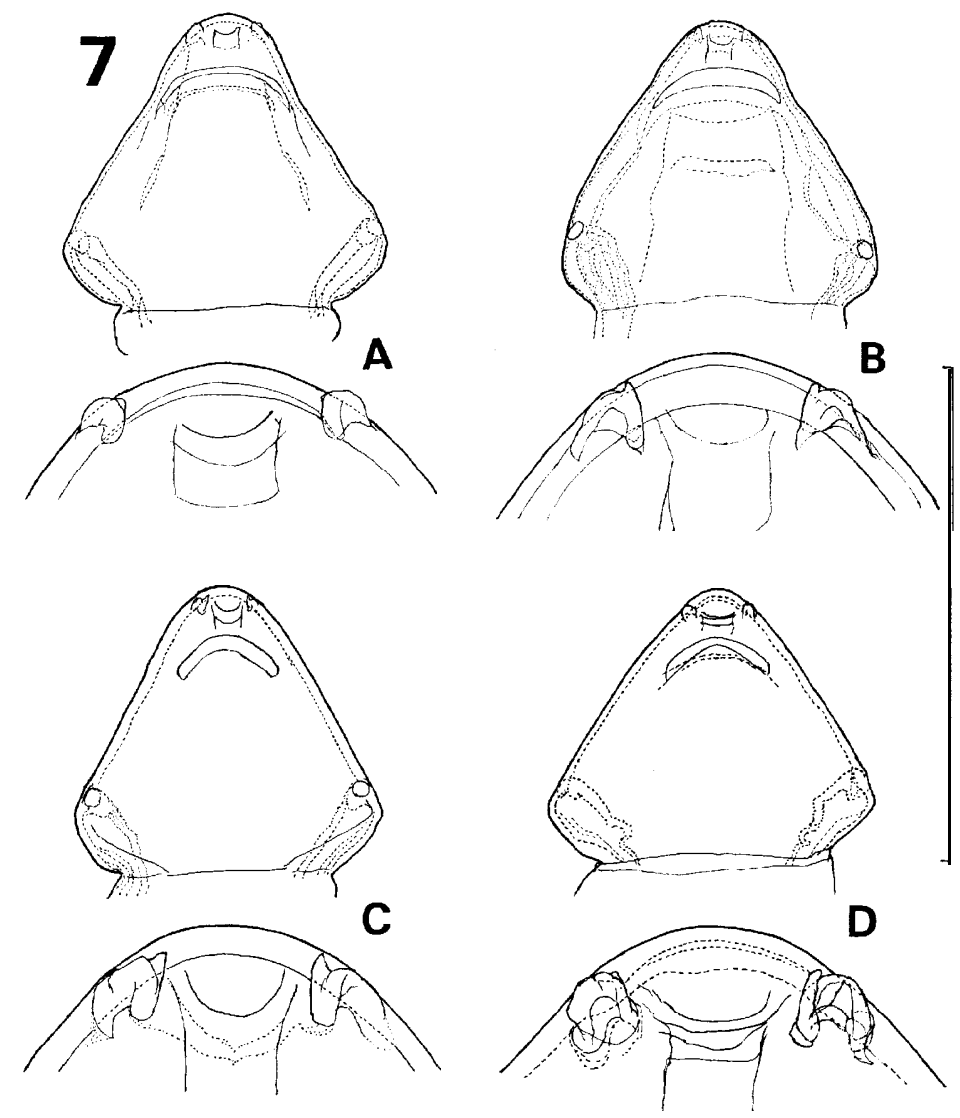

Fig. 7. Female cephalothorax, ventral view. Scale: $1 \mathrm{~mm}$ for the top each, $0.25 \mathrm{~mm}$ for the bottom each. A-D: Same as in Fig. 1.

fused with scuti; postlumbium pentagonal, posterior margin arcuate ; postscutellum distinctly broad at base, subpentagonal; hind femora without blunt process at the postero-interior angle ; aedeagus with inconspicuous dorsal process and bluntly pointed, triangular, ventral projection.

Female (Fig. 7, C).

Size. Total length of body $2.7-3 \mathrm{~mm}$; cephalothorax 0.54-0. $58 \mathrm{~mm}$ in length and $0.58-0.59 \mathrm{~mm}$ in breadth at a little posterior to spiracles; basal breadth of abdomen 0.41-o. $42 \mathrm{~mm}$.

Structure. Cephalothorax triangular, almost straight lateral margins without constriction at the level of opening of brood chamber which is strongly arcuate; lateral margins of the opening not so close to the lateral margins of 
cephalothorax ; mandibles with rather large teeth at antero-interior angle; posterior margin of mouth remarkably curved, semicircular.

Host : Halictus aerarius Smith (Hymenoptera : Halictidae).

Type material: Holotype male (Type No. 2381, Kyushu Univ.), Kuriyagawa, Morioka, Iwate Pref., 16. IX. 1970; 2 paratopotype females from one host, 14. IX. 1970; 1 paratopotype male, 14. IX. 1970. All of the type specimens were collected and mounted by Y. Maeta. They are preserved in the Entomological Laboratory, Faculty of Agriculture, Kyushu University.

Other specimens examined: 1 male and 2 females, from one host, same locality as above, 18. IX. 1970 (Y. Maeta), mounted, in Kifune's collection.

REMARKS: The present species is distinguishable from the preceding two species by the hind femora without blunt process and rather conical shapes of maxillary palpal segments in the male and conspicuous teeth of mandibles and strongly arcuate mouth in the female. It is noteworthy that this species is collected in autumn as in other exotic species.

\section{Halictoxenos mirabilis, new species}

Male (Figs. 1-2, 4-6: D).

Size. Total length of body $2.1 \mathrm{~mm}$; length of head and thorax together $1.65 \mathrm{~mm}$; head breadth $0.58 \mathrm{~mm}$; metathoracic breadth $0.65 \mathrm{~mm}$; radial length of hind wing $1.8 \mathrm{~mm}$; length of aedeagus $0.15 \mathrm{~mm}$.

Structure. Closely allied to the preceding species. Vertex between antennal basements not so prominently protruded; maxillary palpi a little longer than mandibles; anterior margin of prothorax gently curved; scutellum triangular, its anterior angle slightly fused with scuti; posterior margin of postlumbium semicircular ; postscutellum conical ; legs a little slender.

Female (Fig. $7:$ D).

Size. Total length of body 2.8-3.0 mm; length of cephalothorax $0.54 \mathrm{~mm}$, breadth $0.66 \mathrm{~mm}$, broadest slightly behind spiracles; basal breadth of abdomen $0.48 \mathrm{~mm}$.

Structure. Generally allied to the preceding species. Cephalothorax broaderer than in japonicus; posterior margin of mouth not so curved, mandibles rather elliptical, teeth more minute than in japonicus;intermandibular distance slightly larger than in japonicus.

Host : Halictus aerarius Smith (Hymenoptera : Halictidae).

Type material: Holotype male (Type No. 2382, Kyushu Univ.), artificially extracted from puparium, Mii-machi, Kurume City, Kyushu, 16. VI. 1960 (Y. Maeta); 2 paratopotype females, from one host, 9. IV. 1960 (Y. Maeta). All of the type specimens are deposited in the Entomological Laboratory, Faculty of Agriculture, Kyushu University. 
REMARKS: This is closely allied to japonicus which occurs in northern Honshu, but differs from it by the narrower pro- and mesothoraces, and the shape of scutellum and postlumbium in the male, and the shapes of mandibles and mouth as well as the ratio of the length to the breadth of the cephalothorax in the female.

\section{KEY TO THE JAPANESE SPECIES OF Halictoxenos}

\section{MALES}

1. Hind femur with a postero-interior blunt process; proximal segment of maxillary palpus cylindrical; parasitic on Lasioglossum....

- Hind femur without such process; proximal segment of maxillary palpus conical; parasitic on Halictus.....

2. Anterior margin of prothorax curved anteriorly; postlumbium with triangular posterior margin; aedeagus with sharp ventral projection; parasitic on Lasioglossum trispine.....

latifemoralis, new species

- Anterior margin of prothorax almost straight; postlumbium with round posterior margin; aedeagus with blunt ventral projection ; parasitic on Lasioglossum apristum

borealis, new species

3. Vertex prominently protruded; scutellum trapezoidal, fused with scuti anteriorly ; postlumbium with slightly curved anterior margin ; maxillary palpus cleary longer than mandible; parasitic on Halictus aerarius, and known from

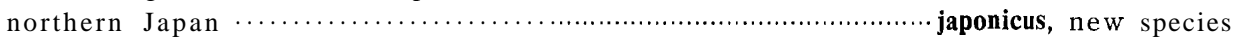

- Vertex slightly protruded ; scutellum almost triangular, weakly fused with scuti anteriorly; maxillary palpus almost as long as mandible ; parasitic on Halictus aerarius, and found in southern Japan ................................ mirabilis, new species

\section{Females}

1. Opening of brood chamber gently arcuate ; lateral margins of it approaching to the lateral margins of cephalothorax; parasites of Lasioglossum $\ldots \ldots * \ldots \ldots \ldots \ldots \ldots * * \ldots 2$

- Opening of brood chamber strongly arcuate; lateral margins of it not so close to the lateral margins of cephalothorax; parasites of Halictus . . . . . . . . ............... 3

2. Cephalothorax broadest just behind spiracles; basal portion of cephalothorax strongly constricted to the abdominal junction; mandible with a minute tooth; parasitic on Lasioglossum trispine ................................ latifemoralis, new species

- Cephalothorax broadest slightly behind spiracles; basal portion of cephalothorax gently constricted to the abdominal junction; mandible with a small triangular tooth ; parasitic on Lasioglossum apristum . . . . . . ............ borealis, new species

3. Posterior margin of mouth strongly curved, semicircular; mandible subtriangular, with a conspicuous tooth; parasitic on Halictus aerarius, and known

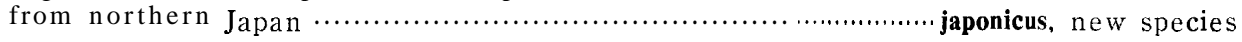

- Posterior margin of mouth gently curved, semielliptical; mandible elliptical, with a very minute tooth; parasitic on Halictus aerarius, found in southern

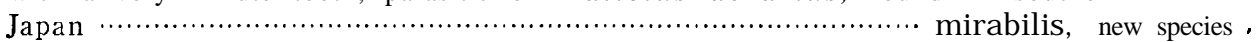

\section{Acknowledgements}

We are grateful to Prof. S. F. Sakagami, Hokkaido University, for his kind entrustment of the stylopized Lasioglossum collected by him in Hokkaido. 


\section{References}

Bohart, R. M. 1941. A revision of the Strepsiptera with special reference to the species of North America. Univ. Calif. Publ. Ent., 7: 91-159.

Kinzelbach, R. K. 1971. Morphologische Befunde an Fächerflüglern und ihre phylogenetische Bedeutung (Insecta: Strepsiptera). Zoologica, (119) : 1-256.

Pierce, W. D. 1908. A preliminary review of the classification of the order Strepsiptera. Proc. ent. Soc. Wash., 9: 75-85.

1909. A monographic revision of the twisted winged insects comprising the order Strepsiptera Kirby. Bull. U. S. Nat. Mus., (66) : I-XII, 1-232, 15 pls. 